\title{
Coulisses
}

Revue de théâtre

15 | Hiver 1997

Varia

\section{CLA et poésie intercontinentale : passeport pour l'Orénoque}

29 et 30 novembre 1996, Salle Quemada, CLA

\section{François Migeot}

\section{OpenEdition}

\section{Journals}

Édition électronique

URL : http://journals.openedition.org/coulisses/5145

DOI : 10.4000/coulisses.5145

ISSN : 2546-9460

\section{Éditeur}

Presses universitaires de Franche-Comté

Édition imprimée

Date de publication : 1 janvier 1997

Pagination : 64

ISSN : 1150-594X

\section{Référence électronique}

François Migeot, «CLA et poésie intercontinentale : passeport pour l'Orénoque », Coulisses [En ligne], 15 | Hiver 1997, mis en ligne le 26 avril 2019, consulté le 31 octobre 2019. URL : http:// journals.openedition.org/coulisses/5145; DOI : 10.4000/coulisses.5145

Ce document a été généré automatiquement le 31 octobre 2019

Coulisses 


\title{
CLA et poésie intercontinentale : passeport pour l'Orénoque
}

\author{
29 et 30 novembre 1996, Salle Quemada, CLA
}

\section{François Migeot}

1 L'association Le Courrier de L'Orénoque offrait ce dernier week-end de novembre un voyage aux amateurs, réunissant pour sa manifestation Passeport pour L'Orénoque, des poètes (Bruno Berchoud, Jean Baptiste Para, François Migeot, Liliane Tuetey, Jacques Moulin, Denise Borias, Luisa Futoransky, Jacques Gaucheron), des musiciens (Benjamin Castro-Balbi, Marc Grivel, Yves Descharmes, le chœur Schütz, Tomas Montilla) et des peintres (Michio Takahashi et Michel Robbe).

2 Désireux d'établir un véritable dialogue entre des horizons culturels divers - France, Amérique Latine, Japon - et diverses formes d'expression artistiques, ce groupe de créateurs et d'animateurs entend se démarquer de la mondialisation, terme ambigu derrière lequel se cache, sous l'apparence d'une ouverture, l'alignement et la standardisation - économique, sociale et culturelle - sur la base de quelques stéréotypes venus d'Outre-Atlantique.

Fidèle, donc, à sa vocation interculturelle et interdisciplinaire, Le Courrier de L'Orénoque a expérimenté une forme de rencontre originale dans laquelle, au voisinage de la peinture, les textes alternaient avec la musique ou dialoguaient avec elle (Liliane Tuetey - Yves Descharmes).

3 Au-delà d'un simple spectacle, ce Passeport a su tisser des liens entre les artistes et un public d'une rare attention, a su faire passer une véritable émotion, et donc faire événement dans la mémoire de tous. A titre de symbole, Tomas Montilla concluait ces journées sur un récital de folklore vénézuélien joué magistralement sur son Cuatro et nous emmenait avec son talent et ses commentaires au bout des plaines du pays de l'Orénoque. 


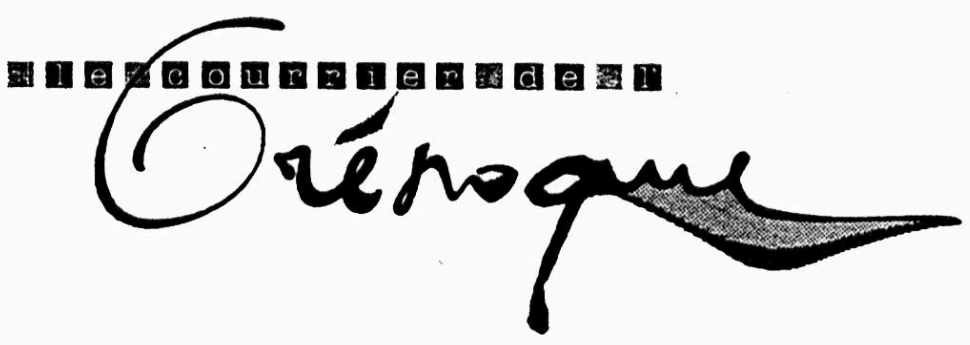

"L'œuvre est un rendez-vous."

Pierre Reverdy 